\title{
Phytochemicals, antioxidant and antimicrobial potentials and LC-MS analysis of hydroalcoholic extracts of leaves and flowers of Erodium glaucophyllum collected from Tunisian Sahara
}

\author{
Sana BAKARI ${ }^{1}$, Hafedh HAJLAOUI ${ }^{2}$, Amal DAOUD ${ }^{1}$, Hedi MIGHRI ${ }^{3}$, José Maria ROSS-GARCIA ${ }^{4}$, \\ Néji GHARSALLAH ${ }^{1}$, Adel KADRI ${ }^{1,5 *}$
}

\begin{abstract}
Erodium glaucophyllum collected from Tunisian Sahara was never presented in the relevant literature yet. In this study, the phytochemical profiles, chemical compositions, antioxidant and antimicrobial activities, and Kill-time assay of the hydroalcoholic extract of flowers and leaves were investigated. The highest content in phenols, flavonoids and tannins was shown in flowers extract ( $350 \pm 5 \mathrm{mg} \mathrm{GAE} / \mathrm{g}, 34 \pm 1 \mathrm{mg} \mathrm{QE} / \mathrm{g}$ and $221.8 \pm 0.0 \mathrm{mg} \beta$-carotene $\mathrm{E} / \mathrm{g}$, respectively). The carotenoids amount in leaves was about 6-fold higher than it's in flowers. Conducted LC/MS analysis revealed the presence of 17 compounds in flowers and leaves extract with the main were quinic acid and naringin followed by rutin, hyperoside, gallic acid and Apegenin-7-oglucoside. Flowers and leaves extracts showed a powerful antimicrobial effect against all strains and the most observed effect was shown with Gram negative bacteria. Time kill kinetics endorses the effectiveness of both extracts to possess bactericidal effect at a concentration less than 2 MIC. Results of both organs open a new promising way for the development of antioxidant and antimicrobial agents for food preservatives against food deterioration.
\end{abstract}

Keywords: Erodium glaucophyllum hydroalcoholic extracts; LC/MS analysis; antioxidant and antimicrobial activities; Kill-time.

Practical Application: The investigation of this novel Sahara plant confirms that this specie was found to be antioxidant and antimicrobial agents for possible therapeutic uses. This plant can also be used in functional food development and for food preservative purposes.

\section{Introduction}

Recently, investigation of natural products for the discovery of active compounds has also developed in finding natural occurring antioxidants for use in foods to replace synthetic antioxidants and antimicrobial agent due to their carcinogenicity (Odeja et al., 2016). Therefore, many desert plants constitute a valuable reserve of new functional compound useful in dietetic foods and pharmaceutical industries. The great diversity of climatic conditions in Tunisia, its dual nature, Mediterranean and African Sahara, gives them a place of choice for the development of a rich and varied flora including great potential aromatic and medicinal plants. Among these plants, Geraniaceae family comprised approximately between 750 and 800 species (Spichiger et al., 2002). Many different authors investigated the chemical content of this family with other Saharian plants species (Bicha et al., 2013; Haddouchi et al., 2016).

The genus Erodium (Geraniaceae) includes 74 species (Keshavarzi et al., 2016). Despite the well-known uses of E. glaucophyllum specie from the Tunisian Sahara called Tamir, Murrar and Dahma (Gohar et al., 2003), still scientific investigation is lacking till now. It was never analyzed for its chemical contents able to protect human health.

This study was designed to evaluate and compare two extracts from different plant organs: flowers and leaves of E. glaucophyllum separately, extracted in terms of their total phenolic (TPC), flavonoids (TFC), condensed tannins (TCT) and carotenoids (TCC). Till now, there are no reports emphases on chemical composition with their biological activities. For this reason, antioxidant and antimicrobial activities and Kill-time assay were evaluated and extracts compositions were analyzed by LC/MS analysis.

\section{Materials and methods}

\subsection{Plant material}

Erodium glaucophyllum was collected at the flowering stage March-April (2014) from the Tunisian Sahara (Latitude $32^{\circ} 55^{\prime} 46^{\prime \prime} \mathrm{N}$, longitude $10^{\circ} 27^{\prime} 06^{\prime \prime}$, altitude $238 \mathrm{~m}$ ) located 
probably at $80 \mathrm{Km}$ from Medenine town in the south of Tunisia. The plant specimen was identified by a recognized botanist. It was deposited at the local herbarium of the biology department of the faculty of Sciences, Sfax, Tunisia.

\subsection{Sample preparation}

Flowering aerial parts (Flowers and Leaves) were air-dried in shade at ambient temperature $\left(20-22^{\circ} \mathrm{C}\right)$ until constant weight (about 20 days). Then, the dried plant materials were coarsely crushed with mortar, grounded in powder with a Moulinex coffee mill (Moulinex, Sfax, Tunisia) and finally stored at $4^{\circ} \mathrm{C}$ until analysis.

\subsection{Standards and reagents}

Folin-Ciocalteu reagent, $\mathrm{Na}_{2} \mathrm{CO}_{3}, 2,2$-Diphenyl-1picrylhydrazyl (DPPH), $\beta$-carotene, ascorbic acid, trichloride ammonium $\left(\mathrm{AlCl}_{3}\right)$, gallic acid, Vanillin, Catechin, ABTS ${ }^{+}$, Trolox, potassium persulfate $\left(\mathrm{K}_{2} \mathrm{~S}_{2} \mathrm{O}_{8}\right), \mathrm{C}_{2} \mathrm{H}_{3} \mathrm{NaO}_{2} \cdot 3 \mathrm{H}_{2} \mathrm{O}, \mathrm{C}_{2} \mathrm{H}_{4} \mathrm{O}_{2}$, TPTZ (2, 4, 6-tripyridyl-s-triazine), $\mathrm{FeCl}_{3} .6 \mathrm{H}_{2} \mathrm{O}$, quercetin, and solvents used for analyses and partitions were all purchased from Sigma-Aldrich (Sigma-Aldrich, France). Spectrophotometric measurements were performed on a double-beam UV-VIS spectrophotometer. For antimicrobial tests, dimethyl sulfoxide (DMSO) was purchased from Sigma (Sigma-Aldrich, France), Mueller Hinton Agar (MHA) and Potato Dextrose Agar (PDA) were purchased from Bio-Rad (Bio-Rad, France).

\subsection{Preparation of the hydroalcoholic extracts}

Hydroalcoholic extraction was performed by stirring the plant material (1g) with $30 \mathrm{~mL}$ of methanol/water $(80: 20, \mathrm{v} / \mathrm{v})$ at $25^{\circ} \mathrm{C}$ and centrifugated at $150 \mathrm{~g}$ for $1 \mathrm{~h}$ and subsequently filtered through Whatman Grade 4 paper. The residue was then extracted with one additional $30 \mathrm{~mL}$ portion of the hydroalcoholic mixture. The combined extracts were evaporated at $35^{\circ} \mathrm{C}$ under reduced pressure (rotary evaporator Büchi R-210, Flawil, Switzerland) and then frozen and lyophilized.

\subsection{Determination of total phenolic, flavonoid, condensed Tannin and carotenoid contents}

The total phenolic, flavonoïd and tannins contents of the hydroalcoholic extracts were quantified by spectrophotometric (Thermo Fisher Scientific, Genesys, Madison, USA) measurement of the absorbance according to the Folin Ciocalteu, using the aluminum chloride and by the vanillin methods, respectively, as reported by Bakari et al. (2015). Furthermore, the total content of carotenoids in extracts was determined according to the method described by Belhaj et al. (2016).

\subsection{Antioxidant activity: DPPH free radical scavenging activity, Ferric-reducing antioxidant power (FRAP) and Scavenging activity of ABTS • + free radical}

The antioxidant capacity of E. glaucophyllum extracts tested using DPPH free radical scavenging and Ferric-reducing power (FRAP) were evaluated by the method described by Cheurfa \& Allem (2016). Total antioxidant activity of hydroalcoholic flowers and leaves extracts was measured in vitro with ABTS assay, and this procedure followed the method described by Ben Nejma et al. (2017) with slight modifications. Each method was replicated three times.

\subsection{LC/MS analysis}

The separation of phenolics was performed with a Shimadzu LC-MS 2020 system equipped with an online degasser (DGU-20A3R), a two binary pump (LC-20ADXR), an autosampler (SIL-20AXR), a column heater (CTO-20AC) and a diode array detector (SPD-M20A). Instrument control and data analysis was carried out using Shimadzu absolution V5.42 SP6 edition through Windows XP. The chromatographic separation was performed using an AQUASIL $\mathrm{C}_{18}$ analytical column (150 mm x $3 \mathrm{~mm} \times 3 \mu \mathrm{m}$ particle size). Used as a stationary phase at $40^{\circ} \mathrm{C}$ as temperature. The mobile phase consisted of methanol with formic Acid (0.1 mL/100 mL methanol) (solvent B) and water with formic Acid as solvent A $(0.1 \mathrm{~mL} / 100 \mathrm{~mL}$ water). The flow rate was kept at $0.4 \mathrm{~mL} / \mathrm{min}$. The gradient elution started with $90 \%$ A/10\% B 0-45 min, 100\% B 45-55 min, $90 \%$ A/10\% B 55-55.1 min, 90\% A/10\% B 55.1-60 min. Photodiode array detector was set at $350 \mathrm{~nm}$ for acquiring chromatograms. The injection volume was $20 \mu \mathrm{L}$ and peaks were monitored at $250 \mathrm{~nm}$. Peak identification was obtained by comparing the retention time and the UV spectra of the fraction phenolic chromatogram with those of pure standards which were purchased from Sigma Aldrich and LGC standards.

Mass spectrometric analysis was performed on a Shimadzu mass spectrometer. Mass spectra data were recorded on an ionization mode for a mass range of $\mathrm{m} / \mathrm{z}$ 50-1500. Other mass spectrometer conditions were as follows: nebulizing gas pressure: 40 psi; drying gas flow: $12 \mathrm{~L} / \mathrm{min}$; drying gas temperature: $400{ }^{\circ} \mathrm{C}$; nebulizing gas flow: $1.5 \mathrm{~L} / \mathrm{min}$. The specific negative ionization modes $\left(\mathrm{m} / \mathrm{z}[\mathrm{M}-\mathrm{H}]^{-}\right)$were used to analyze the compounds.

\subsection{Antimicrobial screening}

The screening of antibacterial activities of hydroalcoholic extracts of E. glaucophyllum was conducted against 8 strains of bacteria including Gram positive bacteria, such as, Bacillus cereus JN 934390, Bacillus subtilis JN 934392, Staphylococcus aureus ATCC 6538, Micrococcus luteus, Enterococcus faecalis, and Gram-negative bacteria as Salmonella enteric serotype enteritidis ATCC43972, Escherichia coli ATCC 25922, and Klebsiella pneumoniae. Antifungal activities were tested using three fungal strains: Fusarium sp. JX391934, Fusarium oxysporum AB586994 and Pythium catenulatum AY598675.

The antimicrobial activity was evaluated by measuring the inhibition zone diameter (IZD), minimum inhibitory concentration (MIC), minimum bactericidal concentration (MBC) and minimum fungicidal concentration (MFC), using a slight modified method as previously described by Daoud et al. (2015). $40 \mathrm{~mL}$ the used agar was poured into petri dishes. After solidification, $150 \mathrm{~mL}$ of the bacterial suspension were speared on the surface. After $5 \mathrm{~min}$ of contact, wells of $6 \mathrm{~mm}$ of diameter were excavated in the agar and each well was filled with $80 \mu \mathrm{L}$ of 
each extract $(75 \mathrm{mg} / \mathrm{mL})$. Finally, the petri dishes were incubated in an oven at $37^{\circ} \mathrm{C}$ for $48 \mathrm{~h}$.

\subsection{Analysis of the Kill-time}

The Kill-time assay is used to determine the bactericidal or bacteriostatic activity of antimicrobials. Time-kill curve analyses were performed using the same method as described by our laboratory (Bakari et al., 2016). Each experiment is carried out three times.

\subsection{Statistical analysis}

All assays were carried out in triplicates and results were reported as mean \pm standard error. The statistical significance between phenolic content and antioxidant activities values of the extract was evaluated with one-way ANOVA followed by LSD test. $\mathrm{P}$ values less than 0.05 were considered to be statistically significant.

\section{Results and discussions}

\subsection{Extraction yield}

Extraction yields of E. glaucophyllum are given in Table 1. After hydroalcoholic extraction, leaves provided higher yield (23.1\%) than the flowers (22.4\%). The lower variation in the yields of both organs might be ascribed to the different availability of extractable components, resulting from the different chemical composition of plants. There are no studies in the literatures concerning yields or any data concerning E. glaucophyllum flowers and leaf extracts.

\subsection{Total phenolics, flavonoids, condensed tannins and carotenoids contents}

The selection of extraction conditions is very important when we research natural phenolic compounds (Felhi et al., 2017). All amounts were reported in Table 1 and values showed great variations in various parts of the studied plant. The leaves extract exhibited the highest level of TPC ( $378 \pm 7$ GAE mg/g) as compared to flowers extract ( $350 \pm 5 \mathrm{GAE} \mathrm{mg} / \mathrm{g}$ ). The above results showed that both organs contained a considerable amount of TPC. The TFC level was about 1.2 times more abundant in flowers $(34 \pm 1 \mathrm{mg} \mathrm{QE} / \mathrm{g})$ than in leaves $(27 \pm 1 \mathrm{mg} \mathrm{QE} / \mathrm{g})$. The TCT were more found in both leaves and flowers extract (221.8 \pm 0.0 against $203.2 \pm 0.1 \mathrm{mg}$ CATE $/ \mathrm{g})$. TCC were less found in flowers $(3.2 \pm 0.7 \mathrm{mg} \beta$-carotene $\mathrm{E} / \mathrm{g})$ as compared to leaves $(26.5 \pm 1.0 \mathrm{mg} \beta$-carotene $\mathrm{E} / \mathrm{g})$. Despite the difference in metabolites and the lower amount of carotenoids found in the hydroalcoholic flower extract, E. glaucophyllum parts were strongly rich in secondary metabolites such as condensed tannins which present almost more than $50 \%$ of the total polyphenolics found in flowers and leaves. A significant difference, at a level $p<0.05$ between the flowers and leaves extracts in the total phenolics, flavonoids, condensed tannins and carotenoids assays, was observed. The present results are in agreement with the previous ones which not only confirm that one of the most effective solvents to obtain phenolics was alcohol such as methanol and ethanol (Felhi et al., 2016) but also clarified that the part screening (leaves and flowers) of the selected species can determine the extraction capacity of phenolic compounds.

The results strongly show that phenolics are important components of this plant, and due to the presence of these valuable constituents, it can have some pharmacological effects or/and can be beneficial for human consumption.

\subsection{Liquid chromatography coupled to mass spectrometry (LC/MS)}

The present study is the first to investigate and identify phenolic compounds of E. glaucophyllum extract from Tunisian Sahara. The LC/MS analysis enabled us to identify 17 phenolic compounds in E. glaucophyllum leaves and flowers extracts separately (Table 2), including 7 phenolic acids: quinic acid, gallic acid, caffeic acid, protocatchuic acid, p-coumaric acid, trans frulic acid and 4,5-di-O-caffeoyquinic acid, and 10 flavonoids: naringin, rutin, hyperoside, quercetin, apegenin-7-o-glucoside, naringenin, luteolin, apergenin, cirsitineol and acacetin.

The predominant compounds of E. glaucophyllum flowers extract were: quinic acid $(\mathrm{Rt}=1.7 \mathrm{~min})$ at $\mathrm{m} / \mathrm{z}=191$, naringin $(\mathrm{Rt}=23.6 \mathrm{~min})$ at $\mathrm{m} / \mathrm{z}=579.0$, rutin $(\mathrm{Rt}=21.8 \mathrm{~min})$ at $\mathrm{m} / \mathrm{z}=609$, hyperoside $(\mathrm{Rt}=22.6 \mathrm{~min})$ at $\mathrm{m} / \mathrm{z}=463$, gallic acid $(\mathrm{Rt}=2.8 \mathrm{~min})$ at $\mathrm{m} / \mathrm{z}=169$ and Apegenin-7-o-glucoside $(\mathrm{Rt}=28.4 \mathrm{~min})$ at $\mathrm{m} / \mathrm{z}=431$. Concentrations of these phenolic acids ranged from 6509.1 to $0.2 \mathrm{mg} / \mathrm{kg}$ (Table 2). The phytochemical characteristics

Table 1. Yields, total phenolic, flavonoid, carotenoids and tannins contents, $\mathrm{IC}_{50}$ and $\mathrm{EC}_{50}$ values of the DPPH free radical scavenging, $\mathrm{ABTS}$ and FRAP assays of both flowers and leaves extracts of E. glaucophyllum. Ascorbic acid and Trolox were used as standards.

\begin{tabular}{|c|c|c|c|c|c|c|c|c|}
\hline \multirow[b]{2}{*}{ Extracts } & \multicolumn{5}{|c|}{ Phytochemical analysis } & \multicolumn{3}{|c|}{ Antioxidant activity } \\
\hline & Yields (\%) & $\begin{array}{c}\text { TPC } \\
\text { (mg GAE/g) }\end{array}$ & $\begin{array}{c}\text { TFC } \\
(\mathrm{mg} \mathrm{QE} / \mathrm{g})\end{array}$ & $\begin{array}{c}\text { TCT } \\
(\mathrm{mg} \mathrm{Cat} / \mathrm{g})\end{array}$ & $\begin{array}{c}\text { TCC } \\
(\mathrm{mg} \beta \text {-carotene } \mathrm{E} / \mathrm{g})\end{array}$ & \multicolumn{2}{|c|}{$\begin{array}{l}\text { DPPH ABTS } \\
\mathrm{IC}_{50}(\mu \mathrm{g} / \mathrm{mL})\end{array}$} & $\begin{array}{c}\text { FRAP } \\
\mathrm{EC}_{50}(\mu \mathrm{g} / \mathrm{mL})\end{array}$ \\
\hline Flowers & 22.4 & $350 \pm 5$ & $34 \pm 1$ & $3.2 \pm 0.7$ & $221.8 \pm 0.0$ & $38.8 \pm 0.2$ & $925.0 \pm 0.7$ & $89 \pm 1$ \\
\hline Leaves & 23.1 & $378 \pm 7$ & $27 \pm 1$ & $27 \pm 1$ & $203.2 \pm 0.2$ & $79.2 \pm 0.6$ & $1054.0 \pm 0.0$ & $111.1 \pm 0.1$ \\
\hline Ascorbic acid & - & - & - & - & - & $114.5 \pm 0.7$ & - & $114.5 \pm 0.7$ \\
\hline Trolox & - & - & - & - & - & - & $430.0 \pm 0.1$ & - \\
\hline
\end{tabular}

The data are expressed as mean \pm S.D. $(\mathrm{n}=3)$; ( $\mathrm{mg}$ GAE/g): $\mathrm{mg}$ of gallic acid equivalent per g of dry plant extract; (mg QE/g): mg of quercetin equivalent per g of dry plant extract; $\mathrm{IC}_{50}(\mu \mathrm{g} / \mathrm{mL})$ : values corresponding to the amount of extract required to scavenge $50 \%$ of radicals present in the reaction mixture; $\mathrm{EC}_{50}(\mu \mathrm{g} / \mathrm{mL})$ : Concentration values corresponding to the amount of extract required to scavenge $50 \%$ of radicals present in the reaction mixture; -: not tested; TPC (Total phenolic content); TFC (Total Flavonoids content); TCT (Total Condensed tannins); TCC (Total Carotenoids content); DPPH (1, 1-Diphenyl-2-Picrylhydrazyl); ABTS ( (2,2'-Azinobis(3-Ethylbenzothiazoline-6-Sulphonic Acid)); FRAP (Ferric Reducing Antioxidant Power). 
Table 2. LC/MS characteristics of phenolic compounds in hydroalcoholic extracts of Erodium glaucophyllum flowers Eg(F) and leaves E.g (L).

\begin{tabular}{|c|c|c|c|c|c|c|}
\hline \multirow{2}{*}{ Peak } & \multirow{2}{*}{ Compounds } & \multicolumn{2}{|c|}{ Concentration $(\mathrm{mg} / \mathrm{kg})$} & \multicolumn{2}{|c|}{ Rt (min) } & \multirow{2}{*}{$\mathrm{m} / \mathrm{z}$} \\
\hline & & E.g $(\mathrm{F})$ & E.g $(\mathrm{L})$ & E.g $g(\mathrm{~F})$ & E. $g(\mathrm{~L})$ & \\
\hline 1 & Quinic acid & 6509.1 & 5940.0 & 1.7 & 1.7 & 191 \\
\hline 2 & Gallic acid & 288.4 & 240.2 & 2.8 & 2.8 & 169 \\
\hline 3 & Protocatchuic acid & 184.2 & 162.4 & 4.3 & 4.3 & 153,109 \\
\hline 4 & Caffeic acid & 0.4 & 0.3 & 8.9 & 8.9 & 179,135 \\
\hline 5 & p-coumaric acid & 3.3 & 3.8 & 13.7 & 13.7 & 163 \\
\hline 6 & Trans frulic acid & 7.1 & 4.8 & 16.8 & 16.8 & 193 \\
\hline 7 & Rutin & 555.1 & 520.5 & 21.8 & 21.8 & 609 \\
\hline 8 & Hyperoside & 529.5 & 497.5 & 22.6 & 22.6 & 463 \\
\hline 9 & Naringin & 855.6 & 755.7 & 23.6 & 23.6 & 579 \\
\hline 10 & Quercetin & 14.4 & 6.9 & 27.3 & 27.3 & 447,337 \\
\hline 11 & Apegenin-7-o-glucoside & 237.8 & 197.9 & 28.4 & 28.8 & 431 \\
\hline 12 & Naringenin & 0.2 & 0.1 & 40.8 & 40.8 & 271 \\
\hline 13 & 4,5-di-O-caffeoyquinic acid & 2.7 & 2.6 & 42.5 & 42.5 & 515 \\
\hline 14 & Luteolin & 26.7 & 23.8 & 42.6 & 42.6 & 285 \\
\hline 15 & Apergenin & 7.2 & 5.8 & 48.7 & 49.0 & 269 \\
\hline 16 & Cirsitineol & 30.1 & 30.0 & 57.2 & 57.2 & 343 \\
\hline 17 & Acacetin & 4.1 & 4.1 & 59.8 & 59.8 & 283 \\
\hline
\end{tabular}

Compounds listed in order of retention time; $\mathrm{Rt}=$ retention time (as $\mathrm{min}$ ).

of E. glaucophyllum leaves extract proved to be very similar to flowers. However, Concentrations of these phenolic acids in leaves differ from those in flowers; They ranged from 5940.0 to $0.1 \mathrm{mg} / \mathrm{kg}$. Overall, LC/MS analysis reflects identical phenolic profile of both organs. It is interesting to note that there are numerous components such as luteolin, quercetin, frulic and caffeic acids found at lower concentrations in both flowers and leaves of E. glaucophyllum.

Previous studies have demonstrated that flavonoids and phenolic acids possess high biological and pharmacological activities (Santos et al., 2016). Park et al., 2016 suggest that hyperoside is one of the phenolic compounds that contribute to the antibacterial and anti-inflammatory proprieties of plants. Also, ferulic acid reacts as a natural protector against ultra-violet radiation known to cause skin disorders such as cancer and acceleration of skin aging. Rutin and gallic acid also help to strengthen veins and to inhibit the formation of amyloid fibrils, the principal causes of Alzheimer's diseases, respectively (Singh et al., 2017).

Phenolic acids, including caffeic and ferulic acids, not only associate with health benefits, but also extend shelf life by avoiding oxidative deterioration of food and by helping to maintain food colours, flavours and nutritional values. Thus, such natural sources of medicinal compounds are useful in pharmaceutics as well as in food industries (Shahidi \& Ambigaipalan, 2015; Ayoub et al., 2016).

\subsection{Antioxidant activity}

Antioxidant properties of different plant extracts and pure compounds can be evaluated using various in vitro assays. In this study, 2,2 -diphenyl-1-picrylhydrazyl (DPPH), Ferric Reducing Antioxidant Power (FRAP) assay and ABTS method were used for evaluating the ability of samples for scavenging free radicals.

\section{DPPH assay}

The scavenging ability of the E. glaucophyllum extracts samples (leaves and flowers) on DPPH free radical was shown in Table 1. The results showed a dose dependent scavenging power. Especially, the scavenging ability of E. glaucophyllum flowers extract increased from $25.2 \pm 1.9 \%$ to $91.9 \pm 0.1 \%$ indicating that it has generally better scavenging ability.

As shown, the lower the $\mathrm{IC}_{50}$ values are, the higher the antioxidant capacity of the flowers and leaves extracts become. With reference to the positive control ascorbic acid, the results revealed that both extracts have very notable antioxidant capacity. We also observed that flowers extract exhibited more potent antioxidant activity than leaves extract, and this was justified by the $\mathrm{DPPH}$ test $\left(\mathrm{IC}_{50}=38.8 \pm 0.2 \mu \mathrm{g} / \mathrm{mL}\right.$, approximately three times lower than standard). Positive correlation was observed between DPPH assay and phenolic compounds for both flowers and leaves extracts, with a high level of significance $(p<0.05)$. This correlation indicated that the richness in phenolic compounds enhances the antioxidant activity of the plant extract.

Usually, higher total phenol and flavonoids contents lead to better DPPH scavenging activity (Kadri et al., 2011; Felhi et al., 2016). As known, polyphenols have a metal chelating potential and their redox properties can be justified by their chemical structure (Li et al., 2008; Schvab et al., 2015). For this reason, the high polyphenolic content in both extracts of E. glaucophyllum may explain the high antioxidant activity of hydroalcoholic extracts.

\section{Scavenging activity of $A B T S^{+}{ }^{+}$free radical}

The principal objective of this test is to measure the capacity of different substances to scavenge the ABTS ${ }^{+}$radical cation. Antioxidant capacities were expressed by $\mathrm{IC}_{50}$ values, indicating the concentrations of extracts scavenge $50 \%$ of $\mathrm{ABTS}^{+}$radical. 
As shown in Table 1 , the $\mathrm{IC}_{50}$ values of the ABTS ${ }^{+}$radical scavenging activity were $925.0 \pm 0.7$ and $1054.0 \pm 0.0 \mu \mathrm{g} / \mathrm{mL}$ for both flowers and leaves extracts, respectively. Comparing these values with standard (Trolox $\mathrm{IC}_{50}=430.0 \pm 0.1 \mu \mathrm{g} / \mathrm{mL}$ ), it is obvious that tested samples are effective to provide their capacity to scavenge the ABTS.+ radical cation at low concentration.

Extracts from flowers and leaves from E. glaucophyllum revealed a high significance level $(\mathrm{p}<0.05)$ between ABTS $^{*}$ radical and TPC. The positive and significant correlation between TPC and ABTS antioxidant activity strengthens the results observed in the DPPH scavenging method used in this study.

This investigation confirms the hypothesis that an increase in total phenolic compounds will increase the antioxidant activity of extracts which has been previously reported (Bakari et al., 2015).

\section{Reducing power: FRAP assay}

Ferric Reducing Antioxidant Power (FRAP) assay is a quantitative assay for measuring the antioxidant potential within a sample. Ferric iron $\left(\mathrm{Fe}^{3+}\right)$ is reduced, by electron-donating antioxidants present in the extracts, to its ferrous form $\left(\mathrm{Fe}^{2+}\right)$. The iron colorimetric probe complex develops a dark blue color product upon reduction. This assay is used to evaluate the capacity of natural antioxidant to donate an electron or hydrogen (Khled khoudja et al., 2014).

Results of reducing power showed that the antioxidants present in the sample reduce the ferric complex $\mathrm{Fe}^{3+}$ into ferrous $\mathrm{Fe}^{2+}$ form. The reducing power was expressed as $\mathrm{EC}_{50}$ (effective concentration at which the absorbance is 0.5 ). The results depicted in Table 1 revealed that flowers hydroalcoholic extract exhibited the potent activity $\left(\mathrm{EC}_{50}=89 \pm 1 \mu \mathrm{g} / \mathrm{mL}\right)$ followed by leaves hydroalcoholic extract $\left(\mathrm{EC}_{50}=111.1 \pm 0.1 \mu \mathrm{g} / \mathrm{mL}\right)$ and the standard ascorbic acid $\left(\mathrm{EC}_{50}=114.5 \pm 0.7 \mu \mathrm{g} / \mathrm{mL}\right)$. Therefore, this study showed that the high levels of phenolic acid compounds found in flowers are the dominant contributors to the antioxidant activity.

The significant correlation between FRAP assay and total phenolic compounds $\left(\mathrm{r}^{2}=0.9\right.$ and $\left.\mathrm{p}<0.05\right)$ supports and confirms that a potent antioxidant activity might be linked to the important amount of polyphenols in extracts and this reinforces the results observed in the DPPH and ABTS methods used in the current study.

In this study, according to the statistical analysis, good correlations $\left(\mathrm{r}^{2}\right)$ were found between antioxidant assays and phenolics: FRAP vs TPC with $0.6 \leq \mathrm{r}^{2} \leq 0.9$, ABTS $v s$ TPC with $\mathrm{r}^{2}=0.9$ and a similar strong correlation was also observed between FRAP, DPPH and ABTS vs TCT with $\mathrm{r}^{2}=0.9$. We noticed that when both flowers and leaves of E. glaucophyllum were comparatively analyzed statistically, the correlation coefficients- among their antioxidant activities based on DPPH, ABTS and FRAP assays -were positively high.

The present findings were in agreement with those of Felhi et al. (2016), which reported a positive correlation between TPC, TFC and TTC. Antioxidant assays indicated that phenolic compounds are often associated with their redox properties, which allow them to act as reducing agents.
Some flavonoids, found in flowers and leaves of E. glaucophyllum, have shown many bioactivities as reported in previous studies and this may explain the potent activity of those extracts. Phenolic acids have considerable interest in the field of food chemistry and medicine because of their promising antioxidant potential (Yasir et al., 2016).

\subsection{Antimicrobial activity}

The antimicrobial activity of E. glaucophyllum leaves and flowers extracts was evaluated according to their IZD, MIC, MBC and MFC values against various strains and the results were compared with the activity of the standards. The obtained results revealed that E. glaucophyllum flowers extract ranged from $15.2 \pm 0.2 \mathrm{~mm}$ for S. aureus and B. subtilis to $32.2 \pm 0.2 \mathrm{~mm}$ for S. Enteritidis. With reference to antibacterial control Chloramphenicol value $16.0 \mathrm{~mm}$ flowers extract indicated a powerful effect. Similarly, E. glaucophyllum leaves recorded a large inhibition zones against tested bacteria ranging from $15.2 \pm 0.3 \mathrm{~mm}$ for $M$. luteus to $28.2 \pm 0.3$ for S. Enteritidis (Table 3). The above results indicated that hydroalcoholic flowers extract of E. glaucophyllum plant exhibited a great antibacterial activity against Gram positive bacteria as well as a greater effect on Gram negative bacteria with the order S. enteritidis $>K$. pneumoniae $>$ E.coli. Among all bacterial strains, Gram negative bacteria are more susceptible than Gram positive bacteria where $S$. Enteritidis demonstrated the highest inhibition for flowers and leaves. The differential sensitivity of Gram positive and Gram negative bacteria to plant extracts may be explained by the morphological differences between the microorganisms (Malanovic \& Lohner, 2016).

Table 3. Antimicrobial activities of flowers and leaves extracts of E. glaucophyllum against fungal and bacterial strains.

\begin{tabular}{|c|c|c|c|}
\hline \multirow{2}{*}{ Strains } & \multicolumn{3}{|c|}{$\operatorname{IZD}(\mathrm{mm})^{*}$} \\
\hline & Flowers & Leaves & Controls \\
\hline \multicolumn{3}{|c|}{ Gram positive bacteria } & Chloramphenicol \\
\hline Bacillus cereus & $20.2 \pm 0.2$ & $17.5 \pm 0.7$ & $26 \pm 1$ \\
\hline Bacillus subtilis & $15.2 \pm 0.2$ & $17 \pm 2$ & $24 \pm 0$ \\
\hline $\begin{array}{l}\text { Staphylococcus } \\
\text { aureus }\end{array}$ & $17 \pm 2$ & $21 \pm 1$ & $16.5 \pm 0.5$ \\
\hline $\begin{array}{l}\text { Micrococcus } \\
\text { luteus }\end{array}$ & $16.0 \pm 0.0$ & $15.2 \pm 0.3$ & $20 \pm 2$ \\
\hline $\begin{array}{l}\text { Enterococcus } \\
\text { faecalis }\end{array}$ & $20.5 \pm 0.5$ & $19.5 \pm 0.7$ & $12 \pm 1$ \\
\hline \multicolumn{4}{|c|}{ Gram negatiive bacteria } \\
\hline $\begin{array}{l}\text { Klebsiella } \\
\text { pneumoniae }\end{array}$ & $25.5 \pm 0.5$ & $25 \pm 1$ & $22 \pm 1$ \\
\hline $\begin{array}{l}\text { Salmonella } \\
\text { enteritidis }\end{array}$ & $32.2 \pm 0.2$ & $28.2 \pm 0.3$ & $16 \pm 0$ \\
\hline Escherichia coli & $20 \pm 2$ & $20.5 \pm 0.7$ & $23.5 \pm 0.5$ \\
\hline Fungal strains & & & Cyclodextrin \\
\hline Penicillium sp. & $11.2 \pm 0.3$ & $13 \pm 1$ & $14 \pm 1$ \\
\hline $\begin{array}{l}\text { Fusarium } \\
\text { oxysporum }\end{array}$ & $24 \pm 2$ & $19 \pm 1$ & $20 \pm 2$ \\
\hline Fusarium sp. & $9.7 \pm 0.3$ & $10.7 \pm 0.3$ & $18 \pm 2$ \\
\hline
\end{tabular}


Tested against three fungal species Penicillium sp., Fusarium sp. and F. oxysporum, the antifungal activity varied greatly and the highest activity was ascribed to F. oxysporum $(24 \pm 2 \mathrm{~mm}$ and $19 \pm 1 \mathrm{~mm}$ ) for both flowers and leaves respectively (Table 3 ).

The difference in the antimicrobial effects of the investigated parts of this plant species may be due to the phytochemical properties and various contents.

As illustrated in Table 4, the hydroalcoholic extracts of the flowers and leaves of the selected plant exhibited antibacterial activity against all bacteria with MIC and MBC values of $0.7-100 \mathrm{mg} / \mathrm{mL}$. The majority of bacterial strains tested were more susceptible to flowers extract compared to leaves extract. The MIC $(1.5 \mathrm{mg} / \mathrm{mL})$ and MBC $(3.1 \mathrm{mg} / \mathrm{mL})$ values of flowers extract illustrated the powerful inhibition growth of $S$. enteritidis.

Regarding fungal activity, F. oxysporum represents the almost susceptible species to extracts $(1.5 \mathrm{mg} / \mathrm{mL}$ and $3.1 \mathrm{mg} / \mathrm{mL}$ for flowers and leaves extracts, respectively). Interestingly, the results showed a significant inhibition activity of E. glaucophyllum extracts against F. oxysporum. The results of this study (Table 4) showed that MIC values of both flowers and leaves hydroalcoholic extract were lower than the MBC values indicating that the plant extracts were bacteriostatic at lower concentration but bactericidal at higher concentration.

The presence of higher concentration of active compounds such as phenolics and tannins could be related to the antimicrobial effect (Giteru et al., 2015).

Heleno et al. (2015) reported that phenolic acids such as protocatechuic, vanillic ferulic and caffeic acids could be used as antimicrobial agents because of the presence of carboxylic acid $(\mathrm{COOH})$, two hydroxyl $(\mathrm{OH})$ groups in para and ortho positions of the benzene ring and also a methoxyl $\left(\mathrm{OCH}_{3}\right)$ group in the meta position.

Table 4. Determination of MIC, MBC and MFC $(\mathrm{mg} / \mathrm{mL})$ of flowers and leaves extracts of E. glaucophyllum.

\begin{tabular}{|c|c|c|c|c|}
\hline \multirow{2}{*}{ Strains } & \multicolumn{2}{|c|}{ Flowers } & \multicolumn{2}{|c|}{ Leaves } \\
\hline & $\mathrm{MIC}^{\mathrm{a}}$ & $\mathrm{MBC}^{\mathrm{b}}$ & $\mathrm{MIC}^{\mathrm{a}}$ & $\mathrm{MBC}^{\mathrm{c}}$ \\
\hline \multicolumn{5}{|l|}{ Gram positive bacteria } \\
\hline Bacillus cereus & 3.1 & 6.2 & 6.2 & 12.5 \\
\hline Bacillus subtilis & 6.2 & 12.5 & 6.2 & 25.0 \\
\hline $\begin{array}{l}\text { Staphylococcus } \\
\text { aureus }\end{array}$ & 3.1 & 12.5 & 12.5 & 25.0 \\
\hline Micrococcus luteus & 3.1 & 12.5 & 6.2 & 12.5 \\
\hline Enterococcus faecalis & 12.5 & 25.0 & 6.2 & 50.0 \\
\hline Gram negatiive bacter & & & & \\
\hline $\begin{array}{l}\text { Klebsiella } \\
\text { pneumoniae }\end{array}$ & 3.1 & 6.2 & 6.2 & 12.5 \\
\hline Salmonella enteritidis & 1.5 & 3.1 & 3.1 & 6.2 \\
\hline Escherichia coli & 6.2 & 12.5 & 3.1 & 6.2 \\
\hline Fungal strains & $\mathrm{MIC}$ & MFC & MIC & MFC \\
\hline Penicillium sp & 6.2 & 25.0 & 6.2 & 12.5 \\
\hline Fusarium oxysporum & 1.5 & 3.12 & 3.1 & 6.2 \\
\hline Fusarium sp. & 6.2 & 12.5 & 12.5 & 25.0 \\
\hline
\end{tabular}

These findings are novel to the best of our knowledge and in agreement, to a certain degree, with the traditional uses of E. glaucophyllum. Accordingly, it could be considered a promising candidate for application as natural preservative additive in various foods and it could be considered as one of the sources of natural antibiotics for medicinal uses, too.

\subsection{Kill-time analysis}

The time-kill profile on E. glaucophyllum flowers and leaves hydroalcoholic extracts is reported for the first time in this study. Therefore, their bactericidal or bacteriostatic potency on S. enteritidis was investigated to confirm its effect and clarify its mechanism of action. The results are summarized in Figure 1 and Figure 2 and are expressed in terms of the $\operatorname{logCFU} / \mathrm{mL}$ over 60.

As depicted in Figure 1, the treatment of S. enteritidis with $1 \mathrm{MIC}(1.5 \mathrm{mg} / \mathrm{mL})$ of flower extract decreased the number of viable cells from 6.4 to $1.8 \log \mathrm{CFU} / \mathrm{mL}$ over $60 \mathrm{~min}$. Incubating the bacteria at $2 \mathrm{MIC}(3.1 \mathrm{mg} / \mathrm{mL}), 4 \mathrm{MIC}(6.2 \mathrm{mg} / \mathrm{mL})$ and

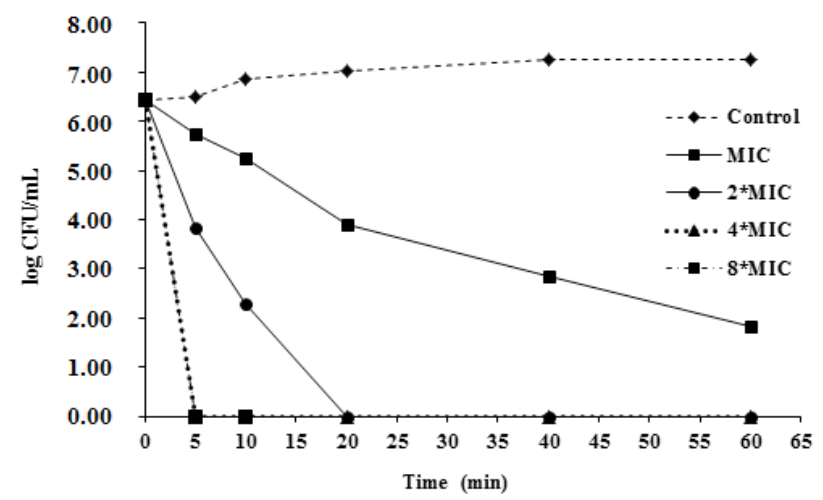

Figure 1. Bactericidal effect of Erodium glaucophyllum flowers hydroalcoholic extract on Salmonella enteritidis strain. Samples were taken at different incubation times and viability was determined by the plate colony count procedure (CFU: colony forming unit).

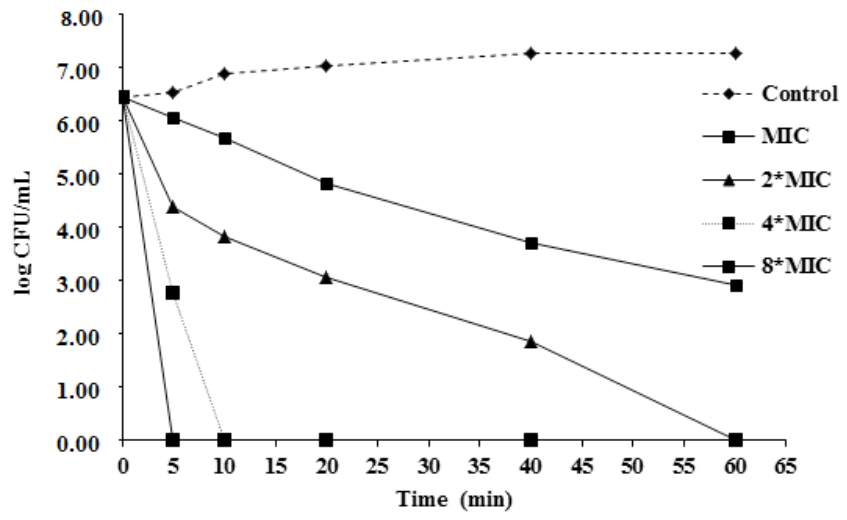

Figure 2. Bactericidal effect of Erodium glaucophyllum leaves hydroalcoholic extract on Salmonella enteritidis strain. Samples were taken at different incubation times and viability was determined by the plate colony count procedure (CFU: colony forming unit). 
8 MIC $(12.5 \mathrm{mg} / \mathrm{mL})$, respectively, no viable cells were observed after $5 \mathrm{~min}$. This means that the bactericidal concentration of flower extract needed to kill $S$. enteritidis should be less than 2 MIC. Leaves extract (Figure 2) also showed a reduction in the number of viable cells from 4.6 to $2.9 \log \mathrm{CFU} / \mathrm{mL}$ within $60 \mathrm{~min}$ after the addition of $1.5 \mathrm{mg} / \mathrm{mL}$ (1MIC) of extract and displayed bactericidal effects. Addition of higher concentrations of 2 MIC, 4 MIC and 8 MIC completely killed S. enteritidis at 5,10 and $60 \mathrm{mn}$, respectively. As a consequence, also for leaves, the bactericidal concentration required to kill $S$. enteritidis should be less than $2 \mathrm{MIC}$.

Therefore, both hydroalcoholic extracts of E. glaucophyllum can be used as a good inhibitor of food microbial growth and as conservation agent.

\section{Conclusion}

This work emphasizes the significant difference in chemical composition between the two organs, flowers and leaves and their significant influence on biological activities. The concentrations of phenolic and carotenoids were determined to be higher in leaves; however flavonoids and tannins were much more abundant in flowers. Both extracts are endowed with potent antioxidant and antimicrobial activities, especially flowers extract. Seventeen phenolic acids were present in higher concentrations in the chromatographic profile of the extracts, with quinic acid and naringin were found in a highest level. In summary, findings reported that E. glaucophyllum could be a natural source of polyphenols compounds with antioxidant and antimicrobial properties.

It will be interesting to draw attention to in vivo tests, to identify and purify phenolic compounds and to confirm the beneficial quality of this Saharian plant. Based on LC/MS analysis and assessment of biological activities, both plant extracts can serve as ingredients of functional foods or may safely be used in pharmaceuticals for treatment of many diseases. Further investigation on the potential of these extract and their interactions with components of food matrices are of good interest.

\section{References}

Ayoub, M., Camargo, A. C., \& Shahidi, F. (2016). Antioxidants and bioactivities of free, esterified and insoluble-bound phenolics from berry seed meals. Food Chemistry, 197(Pt. A), 221-232.

Bakari, S., Daoud, A., Felhi, S., Smaoui, S., Gharsallah, N., \& Kadri, A. (2016). Proximate analysis, mineral composition, phytochemical contents, antioxidant and antimicrobial activities and GC-MS investigation of various solvent extracts of cactus cladode. Food Science and Technology, 37(2), 286-293. http://dx.doi.org/10.1590/1678457x.20116.

Bakari, S., Ncir, M., Felhi, S., Hajlaoui, H., Saoudi, M., Gharsallah, N., \& Kadri, A. (2015). Chemical composition and in vitro evaluation of total phenolic, flavonoid, and antioxydant properties of essential oil and solvent extract from the aerial parts of Teucrium polium grown in Tunisia. Food Science and Biotechnology, 24(6), 1943-1949. http:// dx.doi.org/10.1007/s10068-015-0256-z.

Belhaj, F., Somrani, I., Aissaoui, N., Messaoud, C., Boussaid, M., \& Marzouki, N. (2016). Bioactive compounds contents, antioxidant and antimicrobial activities during ripening of Prunus persica L. varieties from the North West of Tunisia. Food Chemistry, 204, 2936. https://doi.org/10.1016/j.foodchem.2016.02.111.

Ben Nejma, A., Znati, M., Nguir, A., Daich, A., Othman, M., Lawson, A. M., \& Ben Jannet, H. (2017). Phytochemical and biological studies of Tripplex inflata f. Muell.: isolation of secondary bioactive metabolites. The Journal of Pharmacy and Pharmacology, 69(8), 1064-1074. http://dx.doi.org/10.1111/jphp.12735. PMid:28464303.

Bicha, S., Chalard, P., Hammoud, L., Leon, F., Brauard, I., Garcia, V. P., Lobstein, A., Bentamene, A., Benayache, S., Bermejo, J., \& Benayeche, F. (2013). Maroccanin: a new $\gamma$ - lactone and other constituents from Centaurea marroccana Ball, (Asteraceae). Records of Natural Products, 7(2), 114-118.

Cheurfa, M., \& Allem, R. (2016). Evaluation of antioxidant activity of different extracts of Aloysia triphylla leaves (L'Herit.) from Algeria in vitro. Phytothérapie, 14(3), 181-197. http://dx.doi.org/10.1007/ s10298-015-0969-4.

Daoud, A., Malika, D., Bakari, S., Hfaiedh, N., Mnafgui, K., Kadri, A., \& Gharsallah, N. (2015). Assessment of polyphenol composition, antioxidant and antimicrobial properties of various extracts of Date Palm Pollen (DPP) from two Tunisian cultivars. Arabian Journal of Chemistry. In press. http://dx.doi.org/10.1016/j.arabjc.2015.07.014.

Felhi, S., Baccouch, N., Ben Salah, H., Smaoui, S., Allouche, N., Gharsallah, N., \& Kadri, A. (2016). Nutritional constituents, phytochemical profiles, in vitro antioxidant and antimicrobial properties, and gas chromatography-mass spectrometry analysis of various solvent extracts from grape seeds (Vitis vinifera L.). Food Science and Biotechnology, 25(6), 1537-1544. http://dx.doi.org/10.1007/s10068-016-0238-9.

Felhi, S., Saoudi, M., Daoud, A., Hajlaoui, H., Ncir, M., Chaabane, R., El Feki A., Gharsallah, N., \& Kadri, A. (2017). Investigation of phytochemical contents, in vitro antioxidant and antibacterial behavior and in vivo anti-inflammatory potential of Ecballium elaterium methanol fruits extract. Food Science and Technology, 37(4), 558-563. http://dx.doi.org/10.1590/1678-457x.26316.

Giteru, S. G., Coorey, R., Bertolatti, D., Watkin, E., Johnson, S., \& Fang, Z. (2015). Physicochemical and antimicrobial properties of citral and quercetin incorporated kafirin-based bioactive films. Food Chemistry, 168, 341-347. http://dx.doi.org/10.1016/j.foodchem.2014.07.077. PMid:25172719.

Gohar, A. A., Lahloub, M. F., \& Niwa, M. (2003). Antibacterial polyphenol from Erodium glaucophyllum. Zeitschrift fur Naturforschung, 58(910), 670-674. PMid:14577629.

Haddouchi, F., Chaouche, T. M., \& Halla, N. (2016). Screening phytochimique, activités antioxydantes et pouvoir hémolytique de quatre plantes sahariennes d'Algérie. Phytothérapie, 1-9. http:// dx.doi.org/10.1007/s10298-016-1086-8.

Heleno, S. A., Martins, A., Queiroz, M. J. R. P., \& Ferreira, I. C. F. R. (2015). Bioactivity of phenolic acids: metabolites versus parent compounds: a review. Food Chemistry, 173, 501-513. http://dx.doi. org/10.1016/j.foodchem.2014.10.057. PMid:25466052.

Kadri, A., Gharsallah, N., Damak, M., \& Gdoura, R. (2011). Chemical composition and in vitro antioxidant properties of essential oil of Ricinus communis L. Journal of Medicinal Plants Research, 5(8), 1466-1470.

Keshavarzi, M., Najafian, E., Zahra, N., \& Seifali, M. (2016). Anatomical study of some Erodium (Geraniaceae) species in Iran. Thaiszia Journal of Botany, 26(1), 11-20.

Khled khoudja, N., Boulekbache-Makhlouf, L., \& Madani, K. (2014). Antioxidant capacity of crude extracts and their solvent fractions of selected Algerian Lamiaceae. Industrial Crops and Products, 52, 177-182. http://dx.doi.org/10.1016/j.indcrop.2013.10.004. 
Li, H. B., Wong, C. C., Cheng, K. W., \& Chen, F. (2008). Antioxidant properties in vitro and total phenolic contents in methanol extracts from medicinal plants. Food Science and Technology, 41(3), 385-390.

Malanovic, N., \& Lohner, K. (2016). Antimicrobial peptides targeting gram-positive bacteria. Pharmaceuticals, 9(3), 59. http://dx.doi. org/10.3390/ph9030059. PMid:27657092.

Odeja, O., Ogwuche, C. E., Elemike, E. E., \& Obi, G. (2016). Phytochemical screening, antioxidant and antimicrobial activities of Acalypha ciliata plant. Clinical Phytoscience, 2(1), 12. http://dx.doi.org/10.1186/ s40816-016-0027-2.

Santos U.P., Campos J.F., Torquato H.F., Paredes-Gamero E.J., Carollo C.A., Estevinho L.M., Picoli Souza K., \& Santos E. L. (2016). Antioxidant, antimicrobial and cytotoxic properties as well as the phenolic content of the extract from Hancornia speciosa. Food Chemistry, 11(12), e0167531. PMID: 27907185. http://dx.doi. org/10.1371/journal.pone.0167531.

Schvab, M. C., Ferreyra, M. M., Davies, C. V., Stefani, A., Cayetano, M. C., Gerard, L. M., \& Gonzalez, R. F. (2015). Effects of orange winemaking variables on antioxidant activity and bioactive compounds. Food Science and Technology, 35(3), 407-413. http:// dx.doi.org/10.1590/1678-457X.6571.

Shahidi, F., \& Ambigaipalan, P. (2015). Phenolics and polyphenolics in foods, beverages and spices: Antioxidant activity and health effects - a review. Journal of Functional Foods, 18(Pt. B), 820-897.

Singh, A., Gupta, R., \& Pandey, R. (2017). Exogenous application of rutin and gallic acid regulate antioxidants and alleviate reactive oxygen generation in Oryza sativa L. Physiology and Molecular Biology of Plants, 23(2), 301-309. http://dx.doi.org/10.1007/s12298017-0430-2. PMid:28461719.

Spichiger, R. E., Savolainen, V. V., Figeat, M., \& Jeanmonod, D. (2002). Botanique systématique des plantes à fleurs. (2ème ed., Collection Biologie). Laussane: Presses Polytechniques et Universitaires Romandes.

Yasir, M., Sultana, B., \& Amicucci, M. (2016). Biological activities of phenolic compounds extracted from Amaranthaceae plants and their LC/ESI-MS/MS profiling. Journal of Functional Foods and Foods, 26, 645-656. http://dx.doi.org/10.1016/j.jff.2016.08.029. 